\title{
Antimicrobial activities of Rhizobium sp. strains against Pseudomonas savastanoi, the agent responsible for the olive knot disease in Algeria
}

\author{
By Kacem Mourad, ${ }^{1 \star}$ Kazouz Fadhila, ${ }^{1}$ Merabet Chahinez, ${ }^{1}$ Rezki Meriem, ${ }^{1}$ de Lajudie Philippe ${ }^{2}$ \\ and Bekki Abdelkader ${ }^{1}$
}

${ }^{1}$ Laboratoire de biotechnologie des Rhizobiums et amélioration des plantes, Univ. Oran Es-Senia, Algérie

${ }^{2}$ Laboratoire des Symbioses Tropicales et Méditerranéennes (LSTM), Campus International de Baillarguet, Montpellier, France

( ${ }^{*}$ Corresponding author: kacemmourad1964@yahoo.fr)

\section{RESUMEN}

Actividades antimicrobianas de cepas de Rhizobium sp. contra Pseudomonas savastanoi, el agente causante de la tuberculosis del olivo en Argelia.

En la presente investigación, seis cepas de Rhizobium aisladas de suelos argelinos fueron estudiadas para conocer su actividad antimicrobiana contra Pseudomonas savastanoi, el agente causante de la tuberculosis del olivo. Rhizobium sp. ORN 24 y ORN 83 produjeron actividad antimicrobiana contra Pseudomonas savastanoi. La actividad antimicrobiana producida por Rhizobium sp. ORN 24 precipitó con sulfato amónico, tuvo un peso molecular entre 1000 y $10000 \mathrm{KDa}$, fue resistente al calor pero sensible a proteasas y detergentes. Estas características sugieren que la sustancia antimicrobial producida por Rhizobium sp. ORN 24 es la bacteriocina natural conocida como rizobiocina 24 . Por el contrario, la actividad antimicrobiana producida por Rhizobium sp. ORN83 no fue precipitable con sulfato amónico, y tuvo un peso molecular menor de $1000 \mathrm{KDa}$, fue lábil al calor y resistente a detergentes y proteasas. Estas características podrían indicar una relación de la sustancia antimicrobiana producida por Rhizobium sp. ORN83 con la "pequeña" bacteriocina descrita en otros Rhizobium.

PALABRAS-CLAVE: Aceitunas - Antagonista - Argelia Bacterocina - Biocontrol - Pseudomonas savastanoi - Rhizobium.

\section{SUMMARY}

Antimicrobial activity of Rhizobium sp. strains against $P$ seudomonas savastanoi, the agent responsible for the olive knot disease in Algeria.

In the present investigation, six Rhizobium strains isolated from Algerian soil were checked for their antimicrobial activity against Pseudomonas savastanoi, the agent responsible for olive knot disease. Rhizobium sp. ORN 24 and ORN 83 were found to produce antimicrobial activities against Pseudomonas savastanoi. The antimicrobial activity produced by Rhizobium sp. ORN24 was precipitable with ammonium sulfate, between 1,000 and $10,000 \mathrm{KDa}$ molecular weight, heat resistant but sensitive to proteases and detergents. These characteristics suggest the bacteriocin nature of the antimicrobial substance produced by Rhizobium sp. ORN24, named rhizobiocin 24. In contrast, the antimicrobial activity produced by Rhizobium sp. ORN83 was not precipitable with ammonium sulfate; it was smaller than $1,000 \mathrm{KDa}$ molecular weight, heat labile, and protease and detergent resistant. These characteristics could indicate the relationship between the antimicrobial substance produced by Rhizobium sp. ORN 83 and the "small" bacteriocins described in other rhizobia.

KEY-WORDS: Algeria - Antagonism - Bacteriocin Biocontrol - Olives - Pseudomonas savastanoi - Rhizobium

\section{INTRODUCTION}

The Mediterranean region is the world's leading olive-growing area, accounting for almost 98 per cent of global olive production. As with all the countries in the Mediterranean region, olive trees are cultivated in Algeria. With an area of 2,400,000 $\mathrm{km}^{2}$, olive groves occupy a total area of 160,800 hectares ( $3 \%$ of world production) distributed essentially in mountainous areas (Bartolini and Petrucelli, 2002,). More than $30 \%$ of the olives produced are conserved and consumed traditionally as a base for soup or as a pickle (Kacem et al., 2006). The remaining $70 \%$ are used for oil.

Because olives can be grown in marginal, saline and waste land where the soil is unsuitable for other crops, their cultivation increases the land value, contributes to soil conservation and helps to combat problems of environmental degradation and desertification. The Algerian government (Ministry of Agriculture of Algeria) has established tree plantations and launched a top-working program of new olive grove plantations (Anonymous, 2006)

Today, olive groves have started to influence the arid and semi arid areas of Algeria, reaching as far as the Sahara area, which was considered unsuitable a few years ago. In all these regions olive groves are planted as intercropping with legumes of forage, legume crops or those associated with other fruit species.

Olive trees are constantly faced with the risk of being attacked by pathogenic bacteria and fungi which can cause severe damage in olive groves. For example, olive nodes or tuberculosis caused by Pseudomonas savastanoi (olive knot) is observed in many areas of Sig, Mascara, Relizan, Mohammadia 
and Remechi of western Algeria. This bacterial disease is characterized by hyperplasia formation on the stems and branches of olive plants and occasionally on the leaves and fruits (Surico, 1986; Lavermicocca et al., 2002; Young et al., 2004).

As we know, the control of olive knot disease is very difficult and the use of copper compounds is one of the conventional practices employed to reduce symptoms. However, the diffuse resistance to copper bactericides among the pathovars of Pseudomonas savastanoi (Wilson and Backman, 1999) requires the development of alternative control methods for bacterial pathogens, such as the use of biological products to lower toxic pesticide residues on fruits and vegetables and to avoid environmental accumulation of chemicals and the consequent development of resistance among pathogens.

Recent studies reveal that most, if not all, major lineages of bacteria produce one or more antimicrobial agents (Hu and Young, 1998; Kacem et al., 2005; Montesinos, 2007; Holtsmark et al., 2006). An increasing number of studies reveal the potential for these active agents to serve as the next generation of antibiotics for use in human health and agricultural settings (van Sluys et al., 2002; Whitehead et al., 2002). Among these antimicrobial agents is a bacteriocin produced by bacteria. Bacteriocins are all ribosomally synthesized proteinaceous compounds and are active against bacteria closely related to the producing bacteria (Tagg et al. 1976; Riley and Wertz, 2002).

Several studies were reported on the bacteriocins active against phytopathogens (Osnat et al., 2005; Kacem, 2007; Holtsmark et al., 2008). The potential of Gram-negative produced bacteriocins as a mean of biological control in fighting plant pathogens has been investigated, influenced by the prevalence of antibiotic resistant phytopathogenic bacteria (McManus, 2002) and growing health concerns associated with chemical pesticides (Cook, 1993). For example, a bacteriocin-producing strain of Pseudomonas solanacearum prevented tobacco wilt infection (Chen and Echandi, 1984). The incidence and severity of bacterial blight infection that causes leaf streak in rice was reduced by treatment with a bacteriocin-producing strain of Xanthomonasoryzae pv oryzae (Sakthivel and Mew, 1991). S. plymithicium produces a colicin-like bacteriocin, which is active against Erwina amylovora. This pathogen is the causative agent of fire blight, a costly disease to the apple and pear industry (Jabrane et al., 2002). A bacteriocin produced by Pseudomonas inhibited the multiplication of Pseudomonas savastanoi, the agent responsible for olive knot disease as well as lesion on a carob tree. (Lavermicocca et al., 2002).

In addition, rhizobial bacteria, which have the capacity to induce the formation of root nodules in the host plant and increase nitrogen fixation (Lerouge et al., 1990; Vargas and Graham, 1989; Pedrosa et al., 2002), have been shown to produce bacteriocins characterized as small, medium or large on the basis of their assumed sizes, diffusion characteristics, and sensitivity to heat and proteolytic enzymes (Schwinghamer and Brockwell, 1978; Gross and Vidaver, 1978; Schripsema et al., 1996). The first description of bacteriocin production by a number of species within the economically important genus Rhizobium was published by Roslycky (1967). Many rhizobial species (bacteriogenic strains) produce bacteriocins, designated as rhizobiocins (Hirsch, 1979; Goel et al., 1999; Sridevi and Mallaiah, 2008). However, the rhizobiocin properties and their effects on phytopathogenic bacteria remain poorly documented in the literature and until now and the antibacterial produced by Rhizobium genus has not yet been explored.

The production of bacteriocins and the competition between species seem tightly connected; it is also possible that future bacteriocin research will reveal new pathways, thus yielding new targets for alternative approaches for plant disease control.

In previous studies (Merabet et al., 2006, Merabet, 2007), rhizobial strains were isolated from root nodules of Medicago ciliaris and Medicago polymorpha, two legumes of forage and ecological importance in Algeria, especially in saline soil regions. By partial sequencing of the gene coding for the 16 S ribosomal RNA, they were found to be affiliated to Rhizobium and Sinorhizobium genera. In this study we report a bacteriocin like substance produced by Rhizobium sp. ORN 24 and ORN 83 strains against Pseudomonas savastanoi and other phytopathogen bacteria. Our investigation includes partial purification and preliminary characterization of the bacteriocins produced.

\section{MATERIALS AND METHODS}

\subsection{Bacterial strains and culture media}

Rhizobium sp. (ORN83, ORN24 and ORN26) and Sinorhizobium sp. (ORN16, ORN88, and ORN89) strains were previously isolated in saline soils in the region of Oran (Algeria) (Merabet et al., 2006; Merabet 2007). Pseudomonas savastanoi CFBP 2074 came from CFBP «Collection Française de Bactéries Phytopathogènes, Angers, France ». It was obtained from INRA (Institut National de la Recherche Agronomique, Algers, Algeria). This strain (Pseudomonas savastanoi CFBP 2074) was isolated from olives cultured in Algeria (lacobellis et al., 1994) and was chosen on the basis of its proven pathogenicity to olives (lacobellis et al., 1994). All strains were maintained as a frozen stock at $-20^{\circ} \mathrm{C}$ in distilled water plus $20 \%(\mathrm{v} / \mathrm{v})$ glycerol and propagated twice in YEM broth (van Brussel et al., 1977) at $28^{\circ} \mathrm{C}$ before use. The other strains used as indicators were tested as follows: lactobacilli (Lactobacillus plantarum) were tested in MRS agar at $30^{\circ} \mathrm{C}$ for $18 \mathrm{~h}$, Propionibacterium strains in YGL agar medium at $37^{\circ} \mathrm{C}$ for $48 \mathrm{~h}$, Pseudomonas in 
Brain Heart Infusion agar at $32{ }^{\circ} \mathrm{C}$ for $48 \mathrm{~h}$, and $E$. coli and Erwinia in Nutrient agar at $37^{\circ} \mathrm{C}$ for 3 days (Kacem, 2007).

\subsection{Bacterial interaction and detection of antimicrobial activity}

Rhizobium sp. (ORN83, ORN24 and ORN26) and Sinorhizobium sp. (ORN16, ORN88, and ORN89) strains were tested for their antagonistic activity against Pseudomonas savastanoi CFBP 2074 by the well diffusion method as previously described by Kacem et al. (2005). Briefly, each strain was propagated in $200 \mathrm{ml}$ YEM broth for $24 \mathrm{~h}$ at $28{ }^{\circ} \mathrm{C}$. Culture was centrifuged $(10.000 \mathrm{rpm}$ for $20 \mathrm{~min}$. at $4{ }^{\circ} \mathrm{C}$ ) and the supernatant was adjusted to $\mathrm{pH} 7.0$ with $3 \mathrm{M} \mathrm{NaOH}$ to exclude the antimicrobial effect of organic acid, followed by filtration of the supernatant through a $0.22-\mu \mathrm{m}$ pore size filter (Gelman Acrodisc 13, Pall Corp., Ann Arbor, USA). This solution was designated as Faction $\mathrm{Fl}^{*}$ and then Pseudomonas savastanoi CFBP 2074 was tested for sensitivity to this fraction as follows: prepoured YEM agar plates were overlaid with $7 \mathrm{ml}$ YEM soft agar containing $0.2 \mathrm{ml}$ $\left(10^{7} \mathrm{cells} / \mathrm{ml}\right.$ suspension of a 2 -day YEM broth culture at $28{ }^{\circ} \mathrm{C}$ ) of Pseudomonas savastanoi CFBP 2074. Wells measuring $5 \mathrm{~mm}$ in diameter were cut into the agar plate by using a sterile Durham tube and $100 \mu \mathrm{l}$ of Fraction I was placed into each well. The plates were incubated at $28^{\circ} \mathrm{C}$ for $18 \mathrm{~h}$ and examined for the appearance of $10 \mathrm{~mm}$ or larger clear zones of inhibition around the wells. Each assay was performed in duplicate.

\subsection{Concentration and partial purification of the inhibitory agent}

Fraction $\mathrm{FI}^{\star}(100 \mathrm{ml})$ was treated with solid ammonium sulphate to $0,30,35,40,45,50,55,60$ and $75 \%(\mathrm{w} / \mathrm{v})$ saturation. The mixtures were stirred for $2 \mathrm{~h}$ at $4{ }^{\circ} \mathrm{C}$ and later centrifuged at $20.000 \mathrm{rpm}$ for $1 \mathrm{~h}\left(4^{\circ} \mathrm{C}\right)$. The precipitate (Fraction $\left.\mathrm{Fl}\right)$ was resuspended in $25 \mathrm{ml}$ of $0.05 \mathrm{M}$ potassium phosphate buffer ( $\mathrm{pH}$ 7.0). Dialysis was followed in a tubular cellulose membrane (Specrapor, 1000 dalton MWco, Fisher Scientific Pittsburgh, PA USA) against the same buffer for $12 \mathrm{~h}$ in spectrapor dialysis tubing (Fraction FII). The assay of the inhibitory agent activity was tested on Pseudomonas savastanoi CFBP 2074 and titer was determined in both the precipitate and supernatant to know which one actually contained the inhibitory agent.

Several aliquots of FII $(1 \mathrm{ml})$ were ultrafiltered through various filtron membranes (Filtron Technology Corp; Northborough, Mass), including $1.000 .000,100.000,10.000$ and $1.000 \mathrm{KDa}$ molecular exclusion sizes. Inhibitory activity was determined in retained and eluted fractions. For the quantification of protein concentration in the different fractions a modification of the Bradford
(1976) method has been used, according to manufacturer's instructions for micro-assay procedure (Bio-rad Protein Assay, Bio-Rad Laboratories, Hercules-CA, USA).

\subsection{Determination of the titer of the inhibitory agent}

The titers of the inhibitory agent were quantified in fraction FII by the critical dilution method as described by Schillinger and Lucke (1989). Two fold serial dilutions of each fraction were made in saline solution. Aliquots of $50 \mu \mathrm{l}$ from each dilution were placed in wells in plates seeded with Pseudomonas savastanoi CFBP 2074 strain. These plates were incubated at $28^{\circ} \mathrm{C}$ for $24 \mathrm{~h}$, and the diameters of the inhibition zones were measured. Each assay was performed in duplicate. The antimicrobial activity of the inhibitory agent was defined as the reciprocal of the highest dilution showing inhibition of the indicator (Pseudomonas savastanoi CFBP 2074) lawn and was expressed in arbitrary units per $\mathrm{ml}(\mathrm{AU} / \mathrm{ml})$.

\subsection{Characterization of the inhibitory agent}

Fraction FII at pH 7.0 was treated with trypsin, -chymotrypsin or protenase K. Enzymes were dissolved in phosphate buffer $(0.1 \mathrm{M}, \mathrm{pH} 6)$ and mixed with FII (1:1) to a final concentration of $1 \mathrm{mg} / \mathrm{ml}$. To demonstrate the effect of $\mathrm{pH}$, the fraction FII was adjusted to $\mathrm{pH}$ values from 2-12 with $4 \mathrm{M} \mathrm{HCl}$ and $4 \mathrm{M} \mathrm{NaOH}$. To test the effect of temperature, the fraction FII was assessed by heating at $100{ }^{\circ} \mathrm{C}$ for $10,15,20$ and $60 \mathrm{~min}$ in a water bath. Samples were withdrawn at different time intervals and the activity was tested on Pseudomonas savastanoi CFBP 2074. Heat resistance was also checked after autoclaving Fraction FII at $121{ }^{\circ} \mathrm{C}$ for 15 minutes. Fraction FII was also treated with Tween 20, Tween 80, SDS (Sodium Dodecyl Sulfat) and Triton X-100 to a final concentration of $1 \%$.

\subsection{Search for the bactericidal activity of the inhibitory agent}

From inhibitory assays conducted with Pseudomonas savastanoi CFBP 2074, samples were taken from inhibition zones (the clear surface of agar) and streaked onto fresh medium agar plates and incubated for $48 \mathrm{~h}$ at $28^{\circ} \mathrm{C}$. Growth or no growth was recorded respectively as bacteriostatic and bactericidal activities of fraction FII (Toba et al., 1991).

\subsection{Search for inhibitory spectrum}

For the determination of the inhibition spectrum of fraction FII, several groups of bacteria were used (Table 1) with the agar diffusion test, using the appropriate agar media and incubation conditions for their growth as indicated in the "Bacterial strains and culture media" section. 


\section{RESULTS}

Two, Rhizobium sp. ORN 24 and ORN83, out of the six Rhizobium strains screened for their antagonistic activity against $P$. savastanoi were found to produce inhibition halos of 10 and $25 \mathrm{~mm}$ on lawns of this strain, respectively. Figure 1 shows the typical antagonism produced by cell free supernatants (fraction $\mathrm{FI}$ ) from Rhizobium sp. ORN24 (designated FI24) and ORN83 (designated Fl83). We can observe that the zone of inhibition produced by $\mathrm{FI} 83$ on indicator plates is extremely clear and large compared to the zone of inhibition produced by $\mathrm{Fl} 24$. Based on the quality and size of the zones of inhibition, Rhizobium sp. ORN83 and ORN24 were therefore considered in this study as antibacterial agent-producing strains.

Concerning the result of the concentration procedure, in the case of Rhizobium sp. ORN83, no activity was detected in the precipitate phase after treatment of the fraction FI83 (up to $75 \%$ ) with solid ammonium sulphate, while activity was only found in the supernatant (designated Fll83), suggesting that the inhibitory agent (s) present in FI83 do not have the ability to precipitate by "salting-out". In addition, the inhibitory activity was not retained when FII83 was ultrafiltered through filtron membranes (1,000-molecular weight cut-off).

In the case of Rhizobium sp. ORN24, table 1 show that the activity recovery was achieved by including ammonium sulphate (55\%) and dialysis. Each step resulted in a considerable loss of protein concentration while, specific activity increases. The antibacterial agent (s) in this fraction (designated FII24) was able to pass through cellulose membranes with a 10,000-molecular weight cut-off but was retained with a 1, 000-molecular weight cut-off. The antibacterial activity of Fll24 or Fll83 was found to be 1600 and $800 \mathrm{AU} / \mathrm{ml}$ respectively.

Since bacteriocins are by definition proteinaceous substances they must be sensitive to at least one proteolytic enzyme. Consequently, protease sensitivity is a key criterion in their characterization. In our case, $\alpha$-chymotrypsin, trypsin or proteinase $\mathrm{K}$ had no effect on the activity of FII83, whereas the inhibitory activity of FII24 was

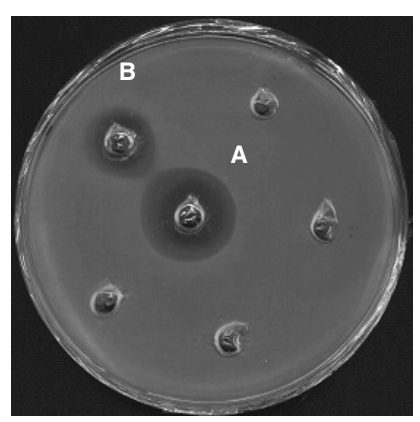

Figure 1

Agar well diffusion assay showing the antibacterial activity of Fl83 from Rhizobium sp. ORN83 and FI24 from Rhizobium ORN24 strains (A) and FI83 from Rhizobium sp. ORN24 (B) strain on Pseudomonas savastanoi CFBP 2074 strain. completely lost by the same enzymes, reflecting the proteinaceous nature of the inhibitory agent produced by Rhizobium sp.ORN24. Additionally, complete inactivation of Fll83 was observed when it was exposed to $100{ }^{\circ} \mathrm{C}$ for $20 \mathrm{~min}$, while Fll24 showed resistance to heat, retaining all activity after exposure to $100{ }^{\circ} \mathrm{C}$ for $60 \mathrm{~min}$. Results appear to indicate that Rhizobium sp. ORN83 produces a small, non-proteinaceous antimicrobial compound and that Rhizobium sp. ORN24 produces a bacteriocin-like peptide.

The other physico-biochemical tests showed that both FII83 and FII24 retained their antibacterial activity within the range of $\mathrm{pH} 4$ to 7 and maintained full stability after storage for 60 days at $4{ }^{\circ} \mathrm{C}, 0{ }^{\circ} \mathrm{C}$ and at $-20{ }^{\circ} \mathrm{C}$, while no activity was detected after storage for 80 to 120 days at $37^{\circ} \mathrm{C}$. Tween 80 , Tween 20, SDS or Triton X-100 seems to have a marked effect on FII24; in contrast the activity of FII83 was not reduced when treated with these agents.

As described in Materials and methods, samples were taken from inhibition zones and surface staked to medium agar plates. After the incubation of plates, the growth of Pseudomonas savastanoi CFBP 2074 was not observed. This result suggests that the antibacterial agents of both FII83 and FII24 are bactericidal toward the target strain. Additionally, strains were resistant to their own cell free supernatants. This may be due to an immunity substance simultaneously being produced by the producer strain along with its product, as in the case of some bacteriocins (Kacem, 2007). The inhibitory spectrum of Fll24 is shown in Table 2.

\section{DISCUSSION}

Research on bacteriocins from bacteria has expanded during the last decades, to include the use of bacteriocins or the antibacterial producer organisms as natural food preservatives (Kacem et al., 2005; Kacem, 2007) and also as biocontrol of many plant pathogens (Holtsmark et al., 2008).

Olive knot are considered to be diseases caused by distinct pathogenic populations in Pseudomonas savastanoi (Young et al., 2004).

Results showed that inhibitory agents are present in cell free supernatants obtained from Rhizobium sp. ORN83 and ORN 24 strains isolated in saline soils from the region of Oran located in western Algeria.

Among the six strains screened for their antagonistic activity, FII83 and FII24 from Rhizobium sp. ORN24 and ORN83 showed an inhibition zone of $10 \mathrm{~mm}$ and $25 \mathrm{~mm}$ in diameter respectively on Pseudomonas savastanoi CFBP 2074 strain. Similar results have been reported by Hirsch (1979) and Rodelas et al. (1998). These authors delineated two types of inhibitions zones produced by Rhizobium genus on indicator plates; the first one was wide (10 to $30 \mathrm{~mm}$ ) and clear due to the production of small bacteriocin, while the 
Table 1

Concentration and partial purification of Fl24 produced by Rhizobium sp. ORN24 strain

\begin{tabular}{|c|c|c|c|c|}
\hline $\begin{array}{l}\text { Purification } \\
\text { Stages }\end{array}$ & $\begin{array}{l}\text { Volume } \\
\text { (ml) }\end{array}$ & $\begin{array}{l}\text { Activity } \\
(\text { AU/ml) }\end{array}$ & $\begin{array}{l}\text { Total protein } \\
(\mu \mathrm{g} / \mathrm{ml})^{2}\end{array}$ & $\begin{array}{l}\text { Specific activity }{ }^{3} \\
\text { (AU/ } / \mu \mathrm{g})\end{array}$ \\
\hline Fraction FI24 & 100 & 400 & 208 & 1.6 \\
\hline FractionFII24 & 10 & 1,600 & 141 & 5.8 \\
\hline \multirow{2}{*}{\multicolumn{2}{|c|}{$\begin{array}{l}\text { Membrane molecular weight } \\
\text { cut-off }\end{array}$}} & \multicolumn{3}{|c|}{ AU (\% Initial activity $)^{4}$} \\
\hline & & & $(\%)$ & Eluted fraction (\%) \\
\hline \multicolumn{2}{|c|}{$1,00,000$} & \multicolumn{2}{|c|}{200 (12.5) } & $800(50.0)$ \\
\hline \multicolumn{2}{|c|}{10,000} & \multicolumn{2}{|c|}{800 (50.0) } & $400(25.0)$ \\
\hline \multicolumn{2}{|c|}{1,000} & \multicolumn{2}{|c|}{$1,600(100.0)$} & $0(0.0)$ \\
\hline
\end{tabular}

${ }^{1}$ Antimicrobial activity of Fraction Fl24 against Sinorhizobium ORN16 strain (AU/ml).

${ }^{2}$ Determined by the Bradford method.

${ }^{3}$ Activity $(\mathrm{AU} / \mathrm{ml})$ (column 2$)$ divided by the protein concentration $(\mu \mathrm{g} / \mathrm{ml})$ (column 3)

${ }^{4}$ Initial bacteriocin activity was $1600 \mathrm{AU} / \mathrm{ml}$.

Fraction FI24: Culture was centrifuged and the supernatant was adjusted to $\mathrm{pH} 7.0$ followed by filtration of the supernatant through a $0.22-$ $\mu \mathrm{m}$ pore size filter.

FractionFII24: Fraction Fl24 was treated with solid ammonium sulphate. The mixtures were centrifuged and re-suspended potassium phosphate buffer ( $\mathrm{pH}$ 7.0). Dialysis was followed in a tubular cellulose membrane.

second one was smaller and turbid $(5$ to $10 \mathrm{~mm})$ due to the production of medium bacteriocin.

FII83 was heat labile, showed resistance to proteolytic enzymes, and produced wide zones of inhibition $(25 \mathrm{~mm})$ on Pseudomonas savastanoi CFBP 2074 strain. However, The FII24 was heat resistant and showed sensitivity to proteases, suggesting that the substance (s) is proteinaceous, or at least has a proteinaceous activator. FII24 produced small zones of inhibition $(10 \mathrm{~mm})$ on the same Pseudomonas savastanoi CFBP 2074 strain. Inhibitory agents in Both FII83 and FII24 were able to pass through cellulose membranes $(10,000$ molecular weight cut-off), suggesting a low molecular weight. Some of the characteristics of our antibacterial substances exhibited properties similar to those of bacteriocins of several rhizobia (Wijffelman et al., 1983; Leroy and De Vuyst, 1999). Hirsch (1979) has described two types of bacteriocins production by Rhizobium leguminosarum; these are designated small and medium bacteriocins. The small bacteriocin is heat labile and resistant to proteolytic enzymes, whereas the medium one is also heat labile but sensitive to proteolytic enzymes. Also, in another study, Schwinghamer and Brockwell (1978) have described the production of bacteriocin by Rhizobium trifolii which is sensitive to heat and proteolytic enzymes. At present, the proteinaceous nature was confirmed for medium bacteriocins and the gene was isolated (Rodelas et al., 1998; Wisniewski, 2002). van Brussel et al., 1985 have reported that the small bacteriocins produced by rhizobia are chloroform soluble and are not required for effective nodulation. Schripsema et al. (1996) described the production of an antimicrobial compound by Rhizobium leguminosarum which they named "bacteriocin small" and resulted to be an $\mathrm{N}$-acyl-Homoserin Lactone molecule. However, classical definition of bacteriocin only includes "peptides or proteins with antimicrobial activity directed against closely related species (Tagg et al., 1976; Jack et al., 1995). Now small bacteriocins have been identified as $\mathrm{N}$-acyl homoserine lactone (Gray et al. 1996; Schripserna et al. 1996) and are therefore structurally related to the quorum sensing factors produced by bacteria.

From these findings and in accordance with the guidelines outlined by several authors (Hirsch, 1979; Wijfelman et al., 1983; Leroy and De Vuyst, 1999) the antibacterial substances present in Fll83 or FII24 can be attributed to a small or medium bacteriocin like respectively.

Fll24 showed inhibition against some Rhizobium sp. and Sinorhizobium sp. strains among the 14 strains tested. As reported by Hafeez et al. (2005), the activity spectrum in Rhisobium genera varied from strain to strain. An auto-antagonism relationship was not observed; no tests strain inhibited its own growth which is characteristic of a bacteriocin producer (Hardy, 1975; Nirmala and Gaur, 2000; Sridevi and Mallaiah, 2008).

Inhibitory activity was also directed against the natural flora present in soil, including Pseudomonas (Pseudomona. aeruginosa 25923), and also against some Erwinia chrysanthemi strains. As we know, these two phytopathogen bacteria can affect many vegetables and cause diseases in plants, including vegetables, root and tuber crops, tree crops and other industrial crops (Toth et al., 1997; Yap et al., 2004), and which result in enormous economic losses annually.

Antimicrobial substances produced by Rhizobium sp. ORN 24 and ORN 83 exhibited inhibitory activity against the phytopathogen with a view to improving the hygiene and safety of food products and vegetable products. Further experiments concerning the effect (in vivo) of this novel bacteriocin on other phytopathogen and the spoilage bacteria are in progress. Finally, all these 
Table 2

Antimicrobial spectrum of Fll24 produced by Rhizobium sp. ORN24 strain against a wide range of indicator strains

\begin{tabular}{|c|c|c|}
\hline Source & Indicator species & Diameter of ${ }^{1}$ inhibition ( $\mathrm{mm}$ ) \\
\hline \multirow{10}{*}{$\begin{array}{c}\text { Medicago ciliaris and } \\
\text { Medicago polymorpha } \\
\text { nodules roots } \\
\text { (Merabet, 2007) } \\
\text { (Merabet et al., 2006) }\end{array}$} & $\begin{array}{l}\text { Rhizobium sp. ORN20, } \\
\text { Rhizobium sp. ORN08 } \\
\text { Rhizobium sp. ORN24 } \\
\text { Rhizobium sp. ORN } 25 \\
\text { Rhizobium sp. ORN } 31\end{array}$ & $\begin{array}{r}19 \\
0 \\
0 \\
0 \\
0\end{array}$ \\
\hline & Rhizobium sp. ORN 38 & 23 \\
\hline & Sinorhizobium sp. ORN11 & 22 \\
\hline & Sinorhizobium sp .ORN16 & 17 \\
\hline & Sinorhizobium sp .ORN20 & 0 \\
\hline & Sinorhizobium sp. ORN41 & 0 \\
\hline & Sinorhizobium sp. ORN42 & 0 \\
\hline & Sinorhizobium sp. ORN49 & 0 \\
\hline & Sinorhizobium sp. ORN51 & 20 \\
\hline & Sinorhizobium sp. ORN55 & 0 \\
\hline \multirow{7}{*}{$\begin{array}{l}\text { Fermented olives } \\
\text { (Kacem et al., 2004) } \\
\text { (Kacem, 2007) }\end{array}$} & Lactobacillus plantarum OL16 & 0 \\
\hline & Lactobacillus plantarum OL12 & 0 \\
\hline & Lactobacillus plantarum OL33 & 12 \\
\hline & Lactobacillus plantarum OL36 & 15 \\
\hline & Lactobacillus plantarum OL53 & 0 \\
\hline & Lactobacillus plantarum OL40 & 0 \\
\hline & Lactobacillus plantarum OL23 & 0 \\
\hline ATCC & E. coli 25922 & 0 \\
\hline (Kacem, 2007) & Pseudomona. aeruginosa 25923 & 24 \\
\hline $\begin{array}{c}\text { CFBP } \\
\text { (lacobellis et al., 1994) }\end{array}$ & Pseudomonas savastanoi CFBP 2074 & 25 \\
\hline \multirow{3}{*}{$\begin{array}{c}\text { ATCC } \\
\text { (Kacem, 2007) }\end{array}$} & P. freudenriechii shermanii 9619 & 13 \\
\hline & P. freudenriechii shermanii 1367 & 13 \\
\hline & P. freudenriechii shermanii 8262 & 13 \\
\hline ATCC & E. chrysanthemi 11663 & 11 \\
\hline CIP & E. chrysanthemi 82.99 & 12 \\
\hline NCPPB & E. chrysanthemi 402 & 11 \\
\hline NCPPB & E. chrysanthemi 2547 & 11 \\
\hline NCPPB & E. chrysanthemi 426 & 15 \\
\hline NCPPB & E. chrysanthemi 2541 & 11 \\
\hline PDDCC & E. chrysanthemi M88 & 11 \\
\hline LBMB* & E. chrysanthemi $5703 a$ & 12 \\
\hline LBMB* & E. chrysanthemi C23 & 12 \\
\hline LBMB $^{*}$ & E. chrysanthemi C26 & 13 \\
\hline (Kacem, 2007) & & \\
\hline
\end{tabular}

CFBP : Collection Française de Bactéries Phytopathogènes» (Angers, France). ATCC: American Type Culture Collection. 12301 (Parklawn Drive, Rockville, Maryland 20852, EE.UU.CIP): Collection of the Institut Pasteur (Rue du Dr. Roux. París 15 France).

NCPPB: National Collection of Plant Pathogenic Bacteria (Plant Pathology Laboratory, Hatching Green, Harpenden, England, U.K). PDDCC: Culture Collection of Plant Diseases Division (New Zealand Department of Scientific and Industrial Research, Auckland. New Zealand). LBMB: Laboratoire de Biologie des Microorganismes et Biotechnologie (Faculté des Sciences, Université d'Oran, Algeria). *: Our strains collection. ${ }^{1:}$ Inhibition essays were done according to the well agar diffusion test (Schillinger and Lücke, 1989.

properties obtained in this study identify Rhizobium sp. ORN 83 and ORN 24 as potential candidates for use in the biocontrol of many plant pathogens, including olives, potatoes, carrots, and cucumbers as well as other vegetable products produced in Algeria.

\section{CONCLUSION}

The exploitation of antimicrobial compounds produced by Rhizobium can constitute an attractive strategy for the targeted combat of bacterial infections, e.g. in plant disease control. The antibacterial substance present in FII24, which we assigned to medium bacteriocin, appear to have the properties commonly associated with "true" bacteriocins and we propose referring to it as rhizobiocin 24, according to the suggestion of Roslycky (1967). More purification to homogeneity of the novel rhizobiocin 24 should be carried out in order to conduct a comprehensive physical characterization of the protein. SDS-PAGE analysis and gel filtration may be used to estimate the size 
of the bacteriocin. The results of the current study open several perspectives for further investigation on this novel bacteriocin including its structure and its possible role during bacterial competition and plant-rhizobial interactions. These findings prompt new interest in bacteriocins produced by plant pathogens that can be considered an alternative bio-control system useful in reducing the hazard associated with the use of synthetic pesticides. Valid formulations to ensure adequate effectiveness of the bactericide under natural environmental conditions should be pursued.

\section{ACKNOWLEDGEMENTS}

This study was supported by a grant of the "Ministère de l'Enseignement Supérieur" of Algeria. Also the authors would like to thank Dr. Philippe de Lajudie (Laboratoire des Symbioses Tropicales et Méditerranéennes: LSTM, Campus International de Baillarguet, Montpellier, France) for his advice and comments on previous versions of the manuscript.

\section{REFERENCES}

Anonymous, 2006. Programme National de Recherche sur les nouvelles technologies: Contribution des recherches biotechnologiques à l'amélioration et à l'accroissement de la production agricole. Haut Commissariat à la Recherche - Algérie.

Bradford, M.B. 1976. A rapid and sensitive method for the quantitation of microgram quantities of protein, utilizing the principle of protein-dye binding. Analys. Biochem. 72, 248.

Chen, W.Y. and Echandi E. 1984. Effects of avirulent bacteriocin-producing strains of Pseudomonassolanacearum on the control of bacterial wilt of tobacco. Plant Pathol. 33, 245-53.

Cook, R.J. 1993. Making greater use of introduced microorganisms for biological control of plant pathogens. Ann Rev. Phytopathol 31, 53-80.

Goel, A. K., Sindhu, S. S.and Dadarwal, K. R., 1999. Bacteriocin-producing native rhizobia of green Gram (Vigna radiata) having competitive advantage in nodule occupancy . Microbiol. Res. 154, 43-48.

Gray, K. M., Pearson J. P., Downie J. A., Boboye B. E. A, and Greenburg E. P.. 1996. Cell-to-cell signaling in the symbiotic nitrogen-fixing bacterium Rhizobium leguminosarum: autoinduction of a stationary phase and rhizosphere-expressed genes. J. Bacteriol. 178, 372-376.

Gross, D. C. and Vidaver A. K. 1978. Bacteriocin-like substances produced by Rhizobium japonicum and other slow-growing rhizobia. Appl. Environ. Microbiol. 36, 936-943.

Hafeez,, F. Y., Naeem, F. I., Naeem, R., Zaidi, A. H. and Malik, K. A. 2005. Symbiotic effectiveness and bacteriocin production by Rhizobium leguminosarum bv. viciae isolated from agriculture soils in Faisalabad. Environ. Exper. Botan. 54, 142-147.

Hardy, K.G., 1975. Colicin ogeny and related phenomena. Bacteriol. Rev. 39, 464-515.

Hirsch, P. R. 1979. Plasmid-determined bacteriocin production by Rhizobium leguminosarum. J. Gen. Microbiol. 113, 219-228.
Holtsmark, I., Mantzilas D., Eijsink V.G.H. and Brurberg M.B. 2006. Purification, characterization, and gene sequence of Michiganin $A$, an actagardine-like lantibiotic produced by the tomato pathogen Clavibacter michiganensis subsp. michiganensis. Appl Environ Microbiol, 72, 5814-5821.

Holtsmark, I., Vincent G.H., Eijsink and Brurberg M. B. 2008. Minireview. Bacteriocins from plant pathogenic bacteria FEMS Microbiol. Lett. 280, 1-7.

Hu, F.P. and Young J.M. 1998. Biocidal activity in plant pathogenic Acidovorax, Burkholderia, Herbaspirillum, Ralstonia and Xanthomonas sp., J. Appl. Microbiol. 84, 263-271.

lacobellis, N. S.,. Sisto A, Surico G., Evidente A., and Di Maio E.. 1994. Pathogenicity of Pseudomonas syringae pv. savastanoi mutants defective in phytohormone production. J. Phytopathol. 140, 238-248.

Jabrane, A., Sabri A., Compere P., Jacques P., Vandenberghe I., Van Beeumen J., Thonart P. 2002. Characterization of serracin $P$, a phagetaillikebacteriocin, and its activity against Erwinia amylovora, the fire blight pathogen. Appl. Environ. Microbiol. 68, 5704-10.

Jack, R., Tagg, J. R., and Ray, B. 1995. Bacteriocins of Gram-positive bacteria. Microbiol Rev 59, 171-200

Kacem, M. 2007. Plasmid DNA studies in Lactobacillus plantarum strains isolated from olive fermentations: production of and immunity to plantaricin OL15 is associated to a $9.6 \mathrm{~Kb}$ plasmid (pOL15) Grasas y Aceites 58, 136-141.

Kacem, M., Zadi-Karam H. and Karam N-E. 2005. Detection and activity of plantaricin OL15, a bacteriocin produced by Lactobacillus plantarum isolated from Algerian fermented olives. Grasas $y$ Aceites 56, 192-197.

Lavermicocca, P., Lonigro S.L., Valerio F., Evidente A. and Visconti A. 2002. Reduction of olive knot disease by a bacteriocin from Pseudomonas syringae pv. ciccaronei. Appl. Environ. Microbiol. 68, 1403-1407.

Lerouge P., Roche P., Faucher. C., Maillet F. and Truchet G.. 1990. Symbiotic hostspecificity of Rhizobium meliloti is determined by a sulphated and acylated glucosamine oligosaccharide signal. Nature 344 , 781-784.

Leroy, F. and De Vuyst L. 1999. Temperature and $\mathrm{pH}$ conditions that prevail during fermentation of sausages are optimal for production of the antilisterial bacteriocin sakacin K. Appl. Environ. Microbiol. 65, 974-981.

Lugtenberg B. J. J. 1985. Bacteriocin small of fast-growing rhizobia is chloroform soluble and is not required for effective nodulation. J. Bacteriol. 162, 1079-1082.

McManus P.S., Stockwell V.O., Sundin G.W. and Jones A.L. 2002. Antibiotic use in plant agriculture. Ann Rev Phytopathol 40, 443-65.

Merabet, C. 2007.Diversité et rôle des rhizobia des régions salées et arides d'Algérie. Thèse de doctorat en Microbiologie Appliquée. Université Senia-Oran, pp. 214.

Merabet, C.; Bekki A.; Benrabah N.,. Bey M., Bouchentouf L., Ameziane H., Rezki M., Domergue A. , CleyetMarel O., Avarre J.-C., Béna G., Bailly X. and de Lajudie P. 2006. Distribution of Medicago Species and Their Microsymbionts in a Saline Region of Algeria Arid Land Res. Management 20, 219-231.

Montesinos, E. 2007. Antimicrobial peptides and plant disease control. FEMS Microbiol Lett 270, 1-11. 
Nirmala, J. and. Gaur Y. D. 2000. Detection of bacteriocinogenic strains of Cicer-Rhizobium by modified simultaneous antagonism method Current. Sci. 79, 286-292.

Osnat, G., Nigro L. M. and Riley M.A. 2005. Genetically Engineered Bacteriocins and their Potential as the Next Generation of Antimicrobials. Curr. Pharmaceut. Design. 11, 138-145.

Pedrosa, F.O., Hungria M. Yates M.G. and Newton W.E. 2000. Nitrogen Fixation: From Molecules to Crop Productivity. Dordrecht: Kluwer Acad. 700 pp.

Riley, M.A. and Wertz J.E. 2002. Bacteriocins: evolution, ecology, and application. Annu. Rev. Microbiol 56, 117-37.

Rodelas, B., Gonzalez-Lopez J., Salmeron V., MartinezToledo M.V. and Pozo C.. 1998. Symbiotic effectiveness and bacteriocin production by Rhizobium leguminosarum bv viceae isolated from agricultural soils in Spain. Appl. Soil Ecol. 8, 51-60.

Roslycky, E. B. 1967. Bacteriocin production in the rhizobia bacteria. Can. J. Microbiol. 13,431-432.

Sakthivel, N, Mew TW. 1991. Efficacy of bacteriocinogenic strains of Xanthomonas-oryzae pv oryzae on the incidence of bacterial-blight disease of rice (Oryza-sativa I). Can. J. Microbiol. 37, 764-8.

Schillinger, U. and F.K. Lücke 1989. Antibacterial activity of L. sake isolated from meat. Appl. Environ. Microbiol. 55, 1901-1906.

Schripsema, J., de Rudder K. E. E., van Vliet, T. B Lankhorst P. P., de Vroom, Kijne E.J. W., and. van Brussel A. A. N. 1996. Bacteriocin small of Rhizobium leguminosarum belongs to the class of $\mathrm{N}$-acyl-Lhomoserine lactone molecules, known as autoinducers and as quorum sensing co-transcription factors. J. Bacteriol. 178, 366-371.

Schwinghamer, E.A.and Brockwell J. 1978; Properties of some bacteriocins produced by Rhimbium trifolii $\mathrm{J}$. Gen. Micro Biol. 9, 403-41 3.

Spaink, H.P., Kondorosi A. and Hooykaas P.J.J. 1998. The Rhizobiaceae: Molecular Biology of Model PlantAssociated Bacteria. Dordrecht: Kluwer Acad. 566 pp.

Sridevi, M. and Mallaiah, K. V. 2008. Production of Bacteriocins by Root Nodule Bacteria. Int. J. Agricul. Res. 3, 161-165.

Surico, G. 1986. Indoleacetic acid and cytokinins in the olive knot disease. An overwiew of their role and their genetic determinants,. In J. Bailey (ed.), Biology and molecular biology of plant-pathogen interactions. NATO ASI series, vol. H1. Springer-Verlag, Berlin, Germany. p. 315-329.
Tagg, J. R., Dajani, A.S. and Wannamaker, L. W. 1976. Bacteriocins of gram positive bacteria. Bacterial. 40, 722-756.

Toba, T., Samant S.K., Yoshioka E. and Itoh T. 1991. Reutericin 6, a new bacteriocin produced by Lactobacillus reuteri LA 6 Lett. Appl. Microbiol. 13, 281-286.

Toth, I.K., Mulholland V., Cooper V., Bentley S., Shih Y.L.. and Perombelon and Salmond G. P. C. 1997. Generalized transduction in the potato blackleg M. C. M. Pathogen Erwinia carotovora subsp. atroseptica by bacteriophage ÊM. Microbiol. 143, 2433-2438.

Van Brussel, A. A. N., Planquk K., and Quispei A.. 1977. The wall of Rhizobium leguminosarurnt in bacteroids and free-living forms. J. Gen. Microbiol. 101,51-56.

Van Brussel, A. A. N.,. Zaat S. A. J, Wijffelman C. A., Pees E., and Van Sluys, M.A., Monteiro-Vitorello C.B., Camargo L.E., Menck C.F., Da Silva A.C., Ferro J.A., Oliveira M.C., Setubal J.C., Kitajima J.P. and Simpson A.J. 2002. Comparative genomic analysis of plantassociated bacteria. Annu. Rev. Phytopathol. 40, 169-189.

Vargas, A.A.T. and Graham, P.H. 1989. Cultivar and pH effects on competition for nodule sites between isolates of Rhizobium in beans. Plant and Soil 117, 195-200.

Whitehead, N.A., Byers J.T., Commander P., 2002. The regulation of virulence in phytopathogenic Erwinia species: quorum sensing, antibiotics and ecological considerations. Dekker, Inc., New York, N.Y. p. 309-335.

Wijffelman, C. A., Pees E.,Van-Brussel A. A. N. and Hooykaas P. J. J. 1983. Repression of small bacteriocin excretion in rhizobium leguminozarum and Rhizobium trifolii by transmissible plasmids. Mol. Genet. 192, 171-176

Wilson, M., and P. A. Backman. 1999. Biological control of plant pathogens. In J. R. Ruberson (ed.), Handbook of pest management. Marcel 2384-2389.

Wisniewski-Dyé F.and Downie J. A. 2002. Quorumsensing in Rhizobium Antonie van Leeuwenhoek 81, 397-407.

Yap, M.N., Barak J. D. and Charkowski A.O. 2004. Genomic diversity of Erwinia genus and its correlation with virulence. Appl. Environ. Microbiol. 70, 3013-3023

Young J.M., 2004. Olive knot disease and its pathogens. Australasian Plant Pathol. 33, 34-39.

Recibido: $7 / 7 / 08$ Aceptado: 26/9/08 